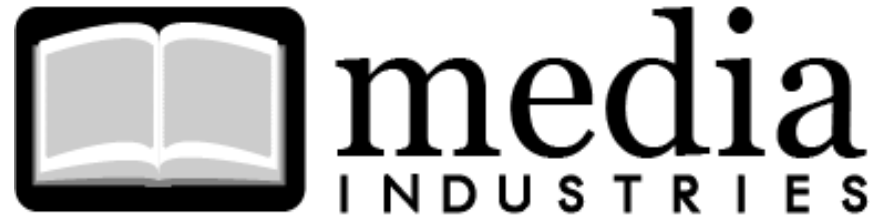

\section{The Rationalizing/Racializing Logic of Capital in Cultural Production}

\author{
Anamik Saha ${ }^{1}$ \\ Goldsmiths, University of London \\ a.saha [AT] gold.ac.uk
}

\begin{abstract}
:
This article conceptualizes the "rationalizing/racializing" logic of capital as a new form of racial governance. This is most evident in cultural production, where the techniques of rationalization-and in particular, the uses of data-that characterize media industry practices produce racializing effects, transforming the potentially disruptive texts of minority producers into absolute ethnic difference. To illustrate this, the article presents an empirical inquiry into the experiences of British South Asian authors in the publishing industry. It focuses on the use of a point-ofsale technology called BookScan, which, it is shown, is the means through which Asian authors come to be pigeonholed by their ethnicity, and subsequently grouped together, impeding their ability to reach wider audiences. In this way the rationalizing/racializing logic of capital represents a new form of racialized governmentality that attempts to manage the counternarratives of difference as they appear in cultural commodities.
\end{abstract}

Keywords: Race, Orientalism, Publishing, BookScan, Big Data

As part of my research into the experience of British South Asian cultural producers working in three cultural industries, I interviewed David, an editorial director at a major UK publishing house. My interest lay in the effects of commercial production upon the representation of Asians in the media and, therefore, the research entailed interviewing (mainly white) cultural intermediaries like David as well as the (mainly Asian) symbol creators themselves. As the husband of a friend, David was someone I had gotten to know quite well prior to our interview. When I asked him whether I could interview him about his experience publishing writers of color (he had worked on Arundhati Roy's The God of Small Things), and ask general questions relating to the publishing industry and the acquisition and promotion of "multicultural fiction" in particular, he initially appeared bemused but agreed. As we walked to the café where we were going to conduct the interview, I again went over what I was going to ask him, reassuring him that the questions would be relatively straightforward. Entering the café, he turned to me and said, "Don't worry, I know what you want to find out."

"You want to find out how racist I am." 
This was clearly a joke - the type two friends make when boundaries of taste are lowered - and we both laughed. Behind this apparently flippant remark, though, was perhaps a pointed reference to the defensiveness of the British publishing industry in relation to its treatment of writers of color-based upon an anxiety around race and ethnicity that David, as a white executive, nonetheless might have felt himself.

In some ways, perhaps more than any other cultural industry in the UK, it is publishing that has seen the greatest inroads made by people of color. Black and Asian British authors such as Salman Rushdie, Hanif Kureshi, Monica Ali, and Zadie Smith have between them sold millions of copies of their novels, giving voice to minority experiences that are ordinarily underrecognized in the West. But the reason I open with the scene above is that, when it comes to publishing stories by writers from minority backgrounds, where the subject itself is the experience of marginality, the industry is ridden with fear and guilt. Scanning through trade magazines like The BookSeller, we find that the few articles dealing with issues of race and culture often frame difference as a problem: the problem of marketing and promoting black and Asian work, the problem of reaching black and Asian audiences, the problem of a lack of diversity in the industry itself. From the point of view of the Asian novelists whom I interviewed, the biggest issue was feeling pigeonholed by their ethnic identity, which was seen as limiting their potential to reach a wider audience. Whether it was the burden of representation and the stories that they felt they were only allowed to tell or the overemphasis of their ethnicity in the promotion of their novels, the overarching theme among my respondents was that the process of getting a book published was a mostly constraining experience. "I want to be known as a writer, not just an Asian writer" was a line I heard on numerous occasions.

When trying to explain the reasons for the negative experiences of writers of color, both the authors and industry personnel to whom I spoke saw this as an outcome of publishing's institutional whiteness, specifically the predominantly white, male, and upper-middle-class nature of the industry's "gatekeepers," as alluded to in the above exchange with David. However, in the publishing industry and throughout the cultural industries in general, the problem of racism is much more entrenched than would be solved by enlightening wellintentioned senior editors and commissioners about the needs of minority authors and audiences, or even taking the more radical step of direct measures to diversify staff at the executive level. As I will argue, it is the very process of industrial cultural production - that is, its techniques and systems of rationalization ${ }^{2}$ - that contain racializing tendencies or, put another way, is the means through which racist ideologies manifest and foster. Moreover, the increasing adoption of new media technologies and big data in cultural production allows this to happen in a more insidious and severe fashion.

In what follows I will present a case study from my research on British Asian cultural production in the publishing industry to demonstrate the way that new media technologies employed in the publishing process - specifically a relatively new piece of point-of-sale tracking software called BookScan - produces racializing effects. I will attempt to explain this in terms of what I call the "rationalizing/racializing logic of capital." In doing so, the article represents an intervention in publishing studies that have generally lacked engagement with issues of race and difference. But more broadly, it contributes to the burgeoning field of race and production studies. ${ }^{3}$ In this current conjuncture, Western society's understandings of race and difference are more than ever shaped by the discourses that appear in media texts, in the form of cultural commodities such as books and films and music videos that are produced through market 
forces that are assumed to be neutral - or indeed, colorblind. On the contrary, this article will demonstrate that the pseudoscientific way in which cultural production is now rationalized and conducted is how racist ideologies are reproduced. Once again we are faced with an instance of appearing "post-race" but being anything but.

\section{The Rationalizing/Racializing Logic of Capital}

In the summer of 2014, an internet meme that exposed the clichéd presentation of South Asia in books went viral. Created by Twitter user @varathas, the meme was titled "South Asian Bookcover Themes in Europe" and was a composite image (Figure 1.) of over fifty book jackets of novels set in India - which all look suspiciously similar. ${ }^{4}$ Arranged into rows with sardonic titles, the covers starkly illustrate the narrow range of Indophilic tropes used to market books relating to South Asia. ${ }^{5}$

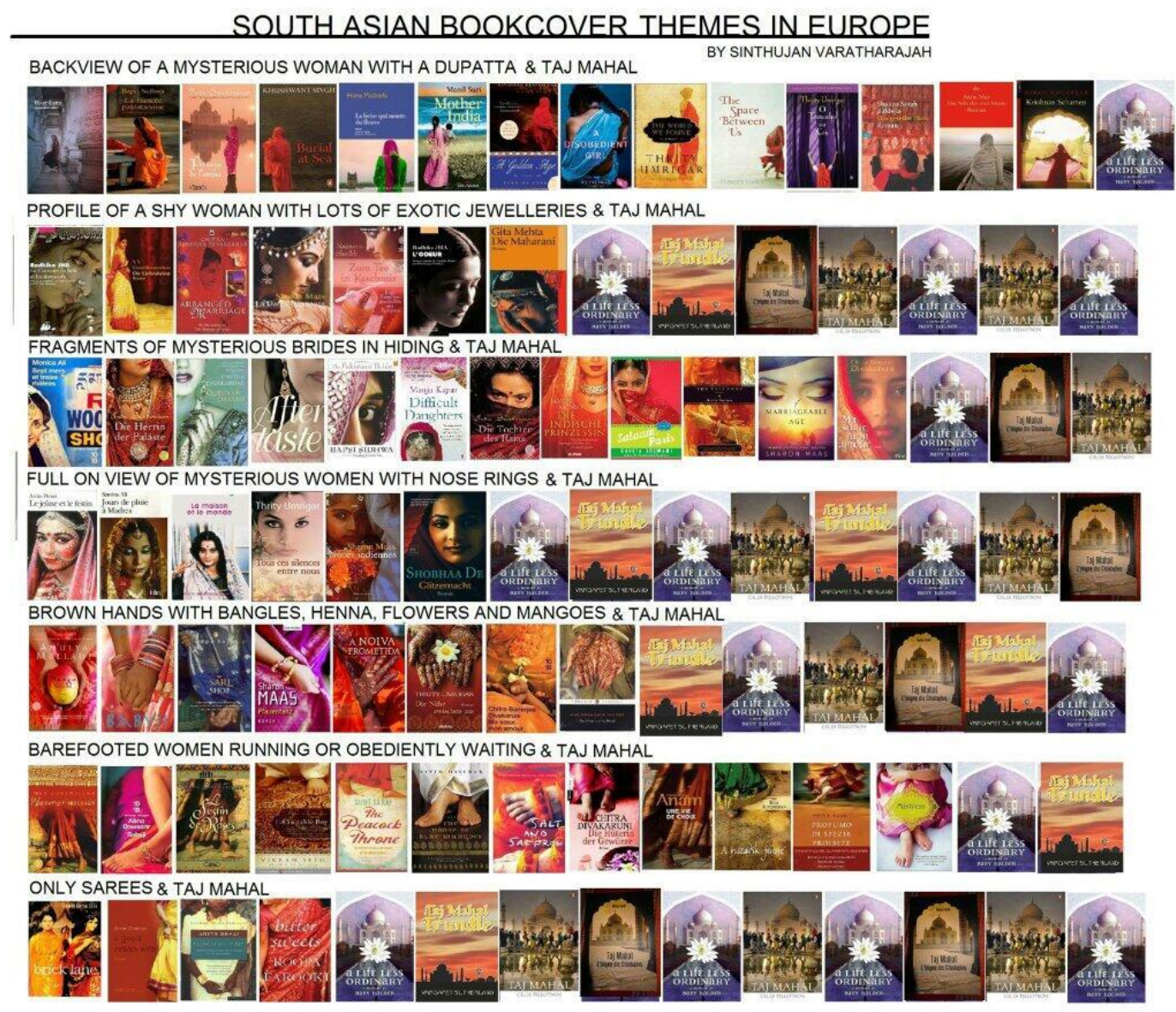

Figure 1. "South Asian Bookcover Themes in Europe." Compiled by Sinthujan Vartharan.

The purpose of the meme was to expose the orientalist ways in which South Asia continues to be presented in the West. The categories are tongue in cheek, particularly the repetition of the Taj Mahal, but nonetheless the effect is clear: through these covers, the diversity of a vast continent is reduced to a romanticized, exoticized, and eroticized Western conception of South Asian culture. 
This image followed another internet meme published in the blog Africa is a Country that provided a similar compilation of book jackets belonging to novels set in Africa that all consisted of the same essential image, what the blogger calls "the acacia tree treatment." 6 The meme was striking in highlighting the ideological uniformity of the representation of Africa through book covers. An article that follows up on the original blog post delves a little deeper and considers the making of such covers, generally pinning the blame on the laziness or ignorance of designers and conservative editors. ${ }^{7}$ Yet a comment from an art director and cover designer interviewed for the piece draws attention to the wider institutional context of publishing when he criticizes "risk-averse marketing departments" for driving the tendency of designers to fall back on orientalist frames.

I use this last point to introduce the idea that racialization, as a process, is intertwined with the rationalized processes of industrial cultural production itself. With rationalization, I am referring to the standardized practices that cultural industries implement to deal with the inherent unpredictability of the market. As Bill Ryan outlines, forms of rationalization include the formatting of the creative process (i.e., creating products according to conventional cultural codes such as genre), marketing centered on the making of "stars and styles" and associated publicity campaigns, and the bureaucratization of the workplace. ${ }^{8}$ For Ryan, these methods of formatting, bureaucratization, marketing, and publicity are the "expression of the rationality of modern capitalism" that characterize what he (following Nicholas Garnham) describes as the corporate age of capitalist production. ${ }^{9}$

In contrast to Ryan's precise and systematic definition of rationalization, racialization is a much more fluid concept, used in myriad ways in a variety of different contexts. Indeed, for Goldberg, studies of race and racism overuse the term racialization to the extent that it loses its conceptual specificity and usefulness. ${ }^{10}$ Nonetheless, I believe the concept has value in describing the social, economic, and cultural processes through which texts/ideas/issues become imbued with racial meaning. I broadly conceive racialization as the ideological process by which minority groups are constructed in ways that, to paraphrase Paul Gilroy, "rely absolutely on an absolute sense of ethnic difference." 11 Gilroy here is specifically referring to the commodification of black culture in regard to the workings of black arts funding, though this can easily be extended to commercial cultural production. It is through the frame of commodification that my definition of racialization is formed, in thinking through how cultural commodities become racialized. This article will demonstrate that within the structural context of the cultural industries, racialization is produced through the rationalization techniques that characterize cultural production in the corporate era. I call this the rationalizing/racializing logic of capital, and I argue that it is the form of racialization that characterizes the postcolonial cultural economy in this neoliberal conjuncture.

The postcolonial cultural economy describes the social, cultural, and economic terrain within which postcolonial epistemes are produced. In an increasingly marketized and commercialized society, the notion of the postcolonial cultural economy underlines how knowledges about the Other are produced predominantly through market and commercial forces. Yet it also challenges simplistic and deterministic accounts of the commodification of the Other that produces somewhat lethargic explanations of the capitalist appropriation of race. Rather, it understands commodification as "complex, ambivalent and contested."12 As Stuart Hall states, while the neoliberal character of globalization tends toward cultural homogenization, it is more accurately characterized as a process marked by contestations. ${ }^{13}$ He continues, 
It is "structured in dominance," but it cannot control or saturate everything within its orbit. Indeed, it produces as one of its unintended effects subaltern formations and emergent tendencies which it cannot control but must try to "hegemonize" or harness to its wider purposes. ${ }^{14}$

Hall seeks to provide a "more discursive model of power in the global environment," one that underlines the potentiality for spaces of resistance and counterstrategies of difference. ${ }^{15}$ But this analysis helps us also understand how within global capitalism, neoliberal economic forces are intertwined with neocolonial ideologies that attempt to totalize and homogenize difference. And it is against this backdrop that the rationalizing/racializing logic of capital takes hold. Put another way, the rationalizing/racializing logic of capital is where ideas about race (themselves formed through political, regulatory, and representational discourses of European/white racism in the West) are allowed to manifest insidiously through what appear as neutral, common sense, commercial rationales.

To demonstrate how this occurs, in what follows I present a case study on the experiences of British Asian authors, and the cultural intermediaries involved in publishing them. This is drawn from a wider empirical study of British South Asian cultural production in three cultural industries-publishing, television, and theater. Applying the "cultural industries" approach that builds upon its political economy foundation a sociological approach to creative labor, the research involved interviews with over fifty cultural producers, creative managers, and executives, participant observation conducted over a year, and a textual analysis of media texts, promotional material, and industry trade magazines. ${ }^{16} \mathrm{My}$ emphasis is on unpacking the "cultures of production" through which British Asian-authored texts are made. ${ }^{17}$ In this way I am able to see how the rationalization techniques implemented at the creative stage of production came to bear upon writers of color in ways that not only constrained their ability to tell the stories they wanted to tell but also paradoxically transformed their attempts to articulate new cosmopolitan imaginaries into absolute ethnic difference. ${ }^{18}$

\section{The Production of "Race" in the Publishing Industry}

As stated above, many of the writers of color that I spoke to identified as their biggest challenge the process of categorization that reduces what they considered universal stories to an exoticized version of their ethnic or racial identity. And as I will demonstrate, this happens through the attempt to apply scientific method-via new media technologies-to the production process. New media technologies have had a major impact on publishing, not least with the emergence of e-books and e-reading devices, which have reduced further what were already low reproduction costs. These new technologies have also had an underestimated effect - that is, on the commissioning process, with potentially damaging epistemological effects for writers of color. ${ }^{19}$

\section{Changing Cultures of Production in the Publishing Industry}

Even before these technological developments, the publishing industry underwent significant changes. In a nutshell, the UK publishing industry was originally based on a patronage model but then evolved into a market-based system. ${ }^{20}$ Following the ascendancy of neoliberal economics in the West from the 1970s onward, publishing has seen "high levels of merger and acquisition activity" with formerly independent publishing houses bought up and integrated into the structures of large corporations. ${ }^{21}$ By 2010 the UK was dominated by just four 
publishing groups that collectively accounted for nearly half the market. In 2013, two of these publishing houses-Penguin and Random House-merged. With intensifying market concentration, publishing houses have seen noticeable changes in their cultures of production, particularly at the commissioning and acquisition stage. ${ }^{22}$

When it comes to acquiring books, publishers receive manuscripts from an author, generally via a literary agent. The overwhelming majority of manuscripts are rejected; but sometimes an editor will receive a book that he or she likes, will deem it as having both literary and commercial potential, and will pitch it to the senior editorial team at an acquisition meeting. During this meeting, a profit and loss statement is produced for every pitched book based upon acquisition costs and predicted sales. These figures are put into a calculation sheet that produces the margin-the greater the margin, the stronger the case for acquiring the book. Where conflict can occur is in the sales prediction. Often an editor and the sales representative, who is also present at the meeting, will disagree about how many copies a book is going to sell, particularly if it involves a new author. Indeed, the recurring theme in my respondents' accounts of commissioning in publishing was the increasing influence of salespeople. For instance, as the owner of a subsidiary company that specializes in black and Asian fiction said to me, sales managers have "more then 50 percent input in the commissioning process." This was described as a negative development. David, the editorial director, conveyed a similar feeling:

What's interesting is that it's the salespeople who give us the figures over whether a new book is going to work or not. It's not done anymore on what I feel in my gut instinct, because there's so much more data around now. And you could say, I feel very passionate about this novel but the salespeople can come back at you and say, "Yes, but no debut novels sell more than ten thousand copies." In fact most of them sell five thousand or three thousand. So what happens is you have to start weaving a little dream: But what if it could be the new Brick Lane?

This comment is useful for its allusion to how quantitative data is being used to manage "gut instinct" and human agency during commissioning/acquisition. But the last point about Brick Lane - a 2003 bestselling novel by British Bengali author, Monica Ali - begins to suggest how the rationalization of cultural work, which attempts to control the unpredictability of not just the market but the behavior of the editor itself, comes to produce racializing effects. This becomes more apparent when we begin to look more closely at how data is used during the acquisition process.

\section{BookScan and Pigeonholing Race}

Sales figures nowadays are obtained from a major development in publishing: a piece of pointof-sale technology called BookScan. BookScan tracks every single sale in the major (and certain independent) bookstores, the figures of which are published weekly.23 BookScan has had a major impact on publishing, not least in being able to more accurately measure sales, and by extension, market share. ${ }^{24}$ But more unexpectedly, its effects have been felt in the commissioning process. One senior editor I spoke to narrated the new acquisition procedure in the following account: 
The big change that has come in the last five years has been something called BookScan, whereby there is a computer program that tracks every single sale of every single book through the tills. So ... every time I take a new book [by a new author] and say I quite like this, I want to do it, our salesperson would go straight to a computer, look it up-or look up something similar, rather-and say, that sold very little; I don't think we should take a risk on this. . So it means people get compared and pigeon-holed much more scientifically now.

According to this narrative, during an acquisition meeting, a novel's projected sales are calculated based on the sales of a similar book. Indeed, this firsthand account of the process of identifying a comparable novel brings into sharp focus the pigeonholing strategies of which the authors I interviewed were critical. Essentially, BookScan, and the practice of pigeonholing and categorization, is part of an attempt to rationalize and standardize the commissioning process (and micro behaviors) where quantitative methods are adopted in order to manage the risk of (human) editorial decisions that do not always produce the optimal commercial results. It is literally a process designed to minimize the high risk that characterizes production in the cultural industries. 25 The editor's comment that authors get "pigeonholed much more scientifically now" produces an explicit indication of how new forms of rationalization eventually lead to the racialization of the British Asian cultural commodity.

BookScan in effect forces commissioners to think in terms of categorization and positioning. British Asian authors subsequently find that their ethnicity informs the category they are placed in, through the format of "multicultural fiction." A male British Asian author whom I interviewed explained his experience of this process as follows:

Interviewer: So they will take a similar novel to yours and make sales projections based on how well that book will do?

Respondent: Yeah. That's quite a depressing thought.

Interviewer: What book do you think they will compare yours to?

Respondent: I don't know, Gautam Malkani or Nirpal Singh-if they can get away from the Asian thing, I think that will be smarter-

Interviewer: To think of you in the same way as David Mitchell, Jon McGregor?

Respondent: Yeah, that's where I would look. But to do that they have to get away from the Asian thing.

David Mitchell and Jon McGregor were two successful and critically acclaimed (white) authors toward whom this published author had earlier expressed an affinity. Yet a certain mentality of commissioners, which he believed reflect the attitudes and values of dominant white society, prevents them from positioning his book with the likes of young, talented British writers such as Mitchell and McGregor or giving it comparable marketing exposure. Instead, he believes he will be categorized alongside two other Asian male authors with whom he felt he shared little in common with stylistically or thematically. The potency in formatting on the basis of race is how these decisions are reached in a way that appears natural and reasonable under the 
branding logic of cultural production. This is made evident in the following exchange with another British Asian author:

Interviewer: Have you found it's the industry that puts labels on you?

Respondent: <pause> I don't know. I just think it's easy in terms of $-<$ pause $>$ I don't know.

Interviewer: Easy for who?

Respondent: For the publisher it's probably easy to say, yeah, er - but, saying that, [my publisher] didn't do that to me because I made a point of not doing it. But a lot of publishers do think, "Yep, British Asian, that's current at the moment, let's put her in that category."

The above author describes a positive relationship with her publisher, whom she feels has not put her in an "Asian" writer category, which this author nevertheless concedes would be an "easy thing to do." The quote also highlights the perception that Asian writers are fashionable and "current" right now, which becomes another common-sense reason for signing an "Asian" text. Thus, the normative terms on which such decisions are reached are notable in that they strip their rationale of its racialist dimensions. As a consequence, such decisions appear to be, at worst, slightly cynical, but at best, rational common sense. David puts it in no-nonsense terms: "If I was a Bangladeshi writer living in London ... I'd mention [Monica Ali's] Brick Lane in my letter, in my opening letter, in my opening sentence of my letter. To be frank, everything is sold as a cross-between."

\section{Formulas of Asianness}

As Keith Negus has demonstrated, producers, faced with the "uncertainties and anxieties" of cultural production and the unpredictability of knowing what is going to succeed, rely upon formulas that are known to have worked in the past. ${ }^{26}$ This logic is unwittingly revealed in a news story in The BookSeller (an industry trade magazine) on the signing of a new young Bengali novelist: "Jane Lawson, who took on Monica Ali's Brick Lane, has bought another tale of cultural collision for Doubleday/Black Swan by 26 year-old newcomer Tina Biswas." 27 Judging from the tone of this short news article, since "cross-cultural collision" worked last time, with Brick Lane, then repeating this formula with another young Asian novelist makes good business sense. The formula-based rationale that characterizes commissioning decisions is exposed in another BookSeller article, which listed the books that followed Bollywood actress Shilpa Shetty's successful biography:28 "Bollywood: A History, Bollywood Crafts, The Bollywood Cookbook, Bollywood Nights, Looking for the Big B: Bollywood, Bachchan and Me, and The Bollywood Reader." 29 Once again, the article is written in a matter-of-fact way, as though these commissions were based on sensible, rational criteria, and, to quote the author above, what was deemed "current."

It is important to unpack the context in which this pattern emerges. When discussing this issue, David, the editorial director, described his experience working on the production of Arundhati Roy's Booker Prize-winning novel The God of Small Things, and the glut of similar narratives on cross-cultural experiences that were published in the wake of Roy's bestseller: 
For the next two years after that, there was so many books that came in from people with mixed upbringings and experiences. So you'd get My Fictionalized Memoir of growing up Sri Lankan or Being Pilipino in New York. It's funny because the agents would send you the submission and it would say this could do what The God of Small Things did for you. Which is kind of interesting, the subtext there... people need boxes.... What's scary now though is with BookScan, people probably will look up the sales figures through the tills for Brick Lane and for The God of Small Things and then will decide how much we should spend on a Guatam Malkani. That's pretty scary.

Here we see directly how the potentially disruptive narrative of cross-cultural entanglements is reduced to a literary formula. ${ }^{30}$ It is interesting to note that David mentioned the author Gautam Malkani several times in our interview. For David, Malkani, who caused a furor within the industry over the reportedly six-figure advance for his debut novel, Londonstani, represents the attempt by publishing houses to repeat past success through following a formula, in this instance, emulating the "multiculturalist" novels of Zadie Smith and Monica Ali. ${ }^{31}$ He explains how, as part of this overarching logic, novels are pitched and bought in this way. David himself described how, one weaves "a little dream" in order to convince sales managers as to why a certain book should be acquired. Yet such a strategy - which David expressed in a way that stresses the human and the emotional qualities of such an appeal - is itself expressed in terms of an economic rationale that sales personnel can understand. While he stressed that this is true not just of narratives on race but also of nationhood and other themes - after all, "people need boxes" - this just further underlines the reductive or, as David put it, the "scary" effects of the normative rationale behind decisions that ultimately decide which novels are acquired and how they are subsequently positioned in the market.

The point is that these particular commissioning decisions and editorial strategies are inextricably bound up in the political economy of publishing. As another senior editor said to me,

Publishing is never going to be a good business model; it's too risky. There are too many books out there to choose from. It's not like there are four major brands of tinned beans - there are two hundred thousand books a year or whatever the crazy stat it is. So what publishers tend to do is they tend to put all of their cash on ten books in a year that they know are going to succeed-Jeffrey Archer's and company-authors who have shown time and time again there is no risk because people will always buy them, and you put all your resources behind them.... And it's getting worse. Publishers are taking fewer risks.

This comment illustrates a common theme in media and communications research that has highlighted how concentration in mass media results in conservatism and a lack of diversity in the range of texts being sold. ${ }^{32}$ Compounded by the nature of cultural production and the impossibility of predicting success, what I have attempted to demonstrate in this case study is how an increasingly competitive marketplace is producing conditions where, as the senior editor above explains, "publishers are taking fewer risks." This has obvious ramifications for 
the British Asian cultural commodity, which is not considered a product that will produce large returns, or indeed, surplus value. Certain exceptions, such as Brick Lane, which sold over half a million copies, have challenged this view. But this has produced a situation where publishers are looking for the next Monica Ali rather than taking a risk on another original voice.

\section{The Science of Pigeonholing}

In Clayton Childress's empirical study into the uses of BookScan in publishing, he aims to counter a straightforward, functionalist reading of its impact that would see it as a mere tool of capital. Childress instead conceptualizes BookScan as a technology that, rather than "totalizing," is "mediated and incorporated into already existing intuitive, taste-based tools for decision-making." 33 He stresses the messy, fragmented, and human nature of cultural production, and how cultural intermediaries mediate between different uses of technology as they do between different types of personnel and rationale. I concur: tools such as BookScan are used in a creative fashion by creative managers (sometimes involving "weaving a little dream") and do not determine cultural production single-handedly.

Yet as I have attempted to demonstrate through this case study, when it comes to the acquisition of writers of color, the use of BookScan has a constraining and damaging effect. Of course, all authors (or at least, the nonwhite/male/heterosexual/middle-class ones) find themselves pigeon-holed according to some facet of their identity. And it is worth stressing that this does not necessarily impede their critical or commercial reception. But I do argue that this process affects writers of color in a very particular and specific way that reproduces neocolonial ideologies. As demonstrated, this includes being pigeonholed with and publicized alongside other minority authors who they have little in common with, stylistically or thematically, or having their books packaged in a way that overdetermines the ethnic or racial identity of the author that, as Huggan shows, results in the exoticization or denigration of the text. ${ }^{34}$ Against the backdrop of market concentration, falling revenues, and highly competitive and pressured work environments, BookScan becomes the means through which racialized attitudes toward minorities are allowed to manifest. As I have suggested, the "rationalizing/racializing logic of capital" describes a new form of "racialized governmentalities" 35 that is characteristic of neoliberalism. In society at large we see the increasing dominance of scientific instruments of knowledge-big data, search engines, recommendation systems, algorithms - that feed, or indeed, direct, the decision-making processes behind production. This in turn produces particular ideological effects for writers of color. To repeat one senior editor quoted earlier on the use of BookScan during cultural production, "it means people get compared and pigeonholed much more scientifically now."

In this context, the use of data-whether sales figures or the size of an author's Twitter following-during cultural production is the means by which race is governed. Data provides the hard and indisputable "evidence" behind what are in fact socially conditioned-and, indeed, racialized - prejudices. Such data is used to manage the expressive cultures of racialized minorities, which either are allowed into discourse if they are acquiescent in some way with the dominant ideology or are marginalized or omitted entirely if they are not. Moreover, the normative, commonsense ways in which this data is used and talked about hides and obscures the racist ideologies that underpin them. In this way the use of data during cultural production, but also in other forms of production and policy-making, constitutes a discourse of having entered the postracial moment-after all, the numbers never lie. 
There remains one more issue in relation to this study, regarding the tension between extracting surplus value versus sustaining racial hierarchies. Above, I quoted an author describing the process of being pigeonholed with other Asian authors. He went on to say that editors are making a mistake by not positioning him alongside other white authors, if not for ethical reasons then for purely commercial ones:

Interviewer: [So you would like publishers to] think of you in the same way as David Mitchell, Jon McGregor?

Respondent: Yeah, that's where I would look. But to do that they have to get away from the Asian thing... I think they could sell more books that way. The whole fucking point is they could do both! But they don't see it like that I feel and perhaps they are right, perhaps the way the country is at the moment you can't do both. I think it's probably about time you started doing both but that requires taking a risk.

The author's exasperation highlights how the marketing of writers of color contains a contradiction: if capitalism were only concerned with profit, then it would be in the best interests of sales and marketing to stress the universal qualities of the cultural commodity rather than brand it according to race, which the respondent believes will limit his audience. Yet through rationalization strategies-identifying unique selling points, market research, data analysis, audience segmentation - the marketing process racializes the cultural commodity in a deeply reductive manner, framed as it is through the orientalist gaze of the dominant culture that in effect runs the media industries. The perverse effect is that the conflation of the producer's ethnic or racial identity with the commodity's brand identity can actually limit the appeal of these particular cultural commodities, which, when not fetishized, are considered repulsive, or at least alien and different. Thus, the contradiction is that stressing the essential difference of the racialized cultural commodity through rationalized marketing strategies appears at odds with the cultural industries focus on audience maximization and capitalism's drive for profit, since its ability to crossover is immediately foreclosed, resulting in less unit sales, ratings, or "bums on seats."

One could conclude then that the cultural industries' key role is in sustaining the regulatory practices of racialized governmentalities rather than accumulating surplus value. But to finish this paper I will instead make a more hopeful - and much less contentious - point that explains the experience of minority practitioners in terms of the ambivalence of cultural commodification. As cultural industries scholars highlight, cultural production relies on novelty and difference, but the unpredictability of the market leads to homogenization and standardization. This is particularly pronounced with minority works-risk is perceived as greater, and therefore its production and distribution is controlled more intensely. Thus, as competition and marketization intensifies this has a detrimental effect for black and Asian work, as cultural industries become even more risk averse. But the inherent contradiction of the cultural commodity ${ }^{36}$ also explains why what Hesse calls "cultural transruptions" can occur. ${ }^{37}$ After all, what could be more "novel" and "different" than racial and ethnic minorities! Thus, there lies the potential for people of color to "break through" and stage critical (multi)cultural interventions that, even just for a moment, disrupt and unsettle the nation's sense of itself (before their narratives in turn become a formula and commodified and reified as essential difference). These are not aberrations or accidents but a product of the enabling tendencies of 
commodification. To repeat Stuart Hall, global capitalism, despite its attempts to totalize, inevitably produces emergent tendencies that it cannot always control. And it is for this reason that Hall believes that "popular culture matters" (and is the only reason in fact that he gives "a damn about it"). 38

\section{Conclusion}

It is easy to see how the commercial imperatives of publishing houses prevent the acquisition of minority works that are deemed too niche. But what is omitted in that analysis is how it is the technologies and processes of rationalization that underpin these decisions through which essentialist ideas about ethnic and racial difference manifest. We see this in the way that the acquisition process estimates the sales for an unpublished novel based on a comparison with a similar published novel, meaning that an Asian novelist will inevitably be bracketed together with other Asian novelists, and subsequently, if acquired, branded in the same way according to an essentialist version of race. As demonstrated, the potency of this ideology is how it is produced through normative rationale. In this way, pigeonholing racialized minorities appears perfectly natural and masquerades as good business practice, or indeed, as scientific.

The challenge, then, is in transforming cultural production. Following Hall's assertion that popular culture matters, the reason why the media matters to minorities - and the reason why so many aspire to work in the media industries - is for its potential to produce critical insights into the experience of belonging to a racialized minority, in the process drawing attention to issues of social (in)justice and (in)equality. However, as this paper has argued, the ability for cultural producers to tell the stories that they want to tell is impeded by the media industries themselves. It is easy to blame this on institutional racism, and the attitudes toward minorities belonging to the industries' predominantly white and middle-class workers (particularly in the case of publishing), shaped by discourses of race produced through political, economic, educational, legal, militaristic, and, indeed, media institutions. Yet diversifying the workforce is not enough. Opening up representational practices depends upon paying greater attention to the processes of cultural production that constrain rather than enable minority practitioners, who are deemed a risky investment from the outset and as such find that the production, distribution, and marketing of their goods are managed much more tightly and conservatively, based in turn upon ethnocentric assumptions about the Other. Thus, the experience of minorities working in the media industry is not just a scholarly concern but also a political one. Finding ways of evading, resisting, or overcoming the rationalizing/racializing logic of capital is absolutely critical to producing effective and meaningful counternarratives of difference.

1 Anamik Saha is a lecturer in the Department of Media and Communications. Before Goldsmiths he worked in the University of Leeds, first as an ESRC Post-Doctoral Fellow and then as a Lecturer in Communications. His research interests are in race and cultural production in its industrial and urban contexts. He has published his work in journals such as Media Culture and Society, Ethnic and Racial Studies, Ethnicities, and European Journal of Cultural Studies. He is currently writing a book entitled Race and the Cultural Industries for Polity Press.

2 Bill Ryan, Making Capital from Culture: The Corporate Form of Capitalist Production (New York: Walter de Gruyter, 1991).

3 David Hesmondhalgh and Anamik Saha, "Race, Ethnicity, and Cultural Production," Popular Communication 11, no. 3 (2013): 179-95. 
4 Sinthujan Varatharajah, Twitter post, May 9, 2014.

5 Vijay Prashad, The Karma of Brown Folk (Minneapolis: University of Minnesota Press, 2000).

${ }^{6}$ Elliot Ross, "The Dangers of a Single Book Cover: The Acacia Tree Meme and 'African Literature,"' Africa Is a Country, May 7, 2014.

${ }^{7}$ Michael Silverberg, "The Reason Every Book About Africa Has the Same Cover-and It's Not Pretty," Quartz, May 12, 2014.

8 Ryan, Making Capital from Culture.

9 Ibid., 30.

${ }^{10}$ David Theo Goldberg, "Racial Americanization," in Racialization: Studies in Theory and Practice, ed. Karim Murji and John Solomos (New York: Oxford University Press, 2005).

11 Paul Gilroy, Small Acts: Thoughts on the Politics of Black Cultures (London: Serpent's Tail, 1993), 111.

12 David Hesmondhalgh, The Cultural Industries, 3rd ed. (Thousand Oaks, CA: Sage, 2013), 25.

13 Stuart Hall, "Conclusion: The Multi-cultural Question," in Un/settled Multiculturalisms: Diasporas, Entanglements, "Transruptions," ed. Barnor Hesse (London: Zed Books, 2000).

${ }^{14}$ Hall, "Conclusion: The Multi-cultural Question", 215.

15 Ibid.

${ }^{16}$ Hesmondhalgh, The Cultural Industries.

${ }^{17}$ K. Negus, "The Production of Culture," in Production of Culture/Cultures of Production (Thousand Oaks, CA: Sage in association with the Open University, 1997), 67-118.

${ }_{18}$ Michael Keith, After the Cosmopolitan? Multicultural Cities and the Future of Racism (New York: Routledge, 2005).

19 See also C. Clayton Childress, "Decision-Making, Market Logic and the Rating Mindset: Negotiating BookScan in the Field of US Trade Publishing," European Journal of Cultural Studies 15, no. 5 (2012): 604-20.

20 Peter Golding, "The International Media and the Political Economy of Publishing," Library Trends, 1978; John B. Thompson, Books in the Digital Age: The Transformation of Academic and Higher Education Publishing in Britain and the United States (Cambridge: Polity, 2005); Patricia H. Thornton and William Ocasio, "Institutional Logics and the Historical Contingency of Power in Organizations: Executive Succession in the Higher Education Publishing Industry, 1958-1990," American Journal of Sociology 105, no. 3 (1999): 801-43.

21 Thompson, Books in the Digital Age, 54.

22 Thompson, Books in the Digital Age; Thornton and Ocasio, "Institutional Logics and the Historical Contingency of Power in Organizations"; Kurt Andrews and Philip M. Napoli, "Changing Market Information Regimes: A Case Study of the Transition to the BookScan Audience Measurement System in the US Book Publishing Industry," Journal of Media Economics 19, no. 1 (2006): 33-54; Childress, "Decision-Making, Market Logic and the Rating Mindset."

${ }^{23}$ Childress, "Decision-Making, Market Logic and the Rating Mindset," 609.

${ }^{24}$ Childress, "Decision-Making, Market Logic and the Rating Mindset"; Andrews and Napoli, "Changing Market Information Regimes."

${ }^{25}$ Garnham, Capitalism and Communication; Hesmondhalgh, The Cultural Industries; Ryan, 
Making Capital from Culture.

${ }^{26}$ Keith Negus, Music Genres and Corporate Cultures (London: Routledge, 1999), 32.

27 "Cross-cultural Collision at Doubleday," The BookSeller, March 17, 2005.

${ }^{28}$ Shetty gained infamy in the UK when she appeared on the Channel 4 reality TV show Celebrity Big Brother and became embroiled in a racism controversy.

29 "Bollywood Dreams," The BookSeller, February 16, 2007.

30 Barnor Hesse, introduction to Un/settled Multiculturalisms: Diasporas, Entanglements, "Transruptions," ed. Barnor Hesse (London: Zed Books, 2000).

31 Rajeev Balasubramanyam, "The Rhetoric of Multiculturalism," in Multi-Ethnic Britain 2000+: New Perspectives in Literature, Film and the Arts, ed. Lars Eckstein et al. (New York: Rodopi, 2008), 31-42.

32 Garnham, Capitalism and Communication; Hesmondhalgh, The Cultural Industries; Hardy, Jonathan. Critical Political Economy of the Media: An Introduction. (London; New York: Routledge, 2014); Bagdikian, Ben H. The New Media Monopoly: A Completely Revised and Updated Edition with Seven New Chapters. (Boston, MA: Beacon Press, 2014).

${ }_{33}$ Childress, "Decision-Making, Market Logic and the Rating Mindset," 616.

${ }^{34}$ Graham Huggan, The Postcolonial Exotic: Marketing the Margins (London: Psychology Press, 2001).

35 Hesse, Introduction, 29.

36 Ryan, Making Capital from Culture.

37 Hesse, Introduction.

38 Stuart Hall, "Notes on Deconstructing 'the Popular,'" in People's History and Socialist Theory, ed. Raphael Samuel, History Workshops Series (London: Routledge and Kegan Paul, 1981), 227-39.

\section{Bibliography}

Andrews, Kurt, and Philip M. Napoli. “Changing Market Information Regimes: A Case Study of the Transition to the BookScan Audience Measurement System in the US Book Publishing Industry." Journal of Media Economics 19, no. 1 (2006): 33-54.

Bagdikian, Ben H. The New Media Monopoly: A Completely Revised and Updated Edition with Seven New Chapters. Boston, MA: Beacon Press, 2014.

Balasubramanyam, Rajeev. "The Rhetoric of Multiculturalism." In Multi-Ethnic Britain 2000+: New Perspectives in Literature, Film and the Arts, edited by Lars Eckstein, Barbara Korte, Eva, Ulrike Pirker, and Christoph Reinfandt, 31-42. New York: Rodopi, 2008.

Childress, C. Clayton. "Decision-Making, Market Logic and the Rating Mindset: Negotiating BookScan in the Field of US Trade Publishing." European Journal of Cultural Studies 15, no. 5 (2012): 604-20.

Garnham, Nicholas. Capitalism and Communication: Global Culture and the Economics of Information. Thousand Oaks, CA: Sage, 1990.

Gilroy, Paul. Small Acts: Thoughts on the Politics of Black Cultures. London: Serpent's Tail, 1993. 
Goldberg, David Theo. "Racial Americanization." In Racialization: Studies in Theory and Practice, edited by Karim Murji and John Solomos. New York: Oxford University Press, 2005.

Golding, Peter. "The International Media and the Political Economy of Publishing." Library Trends, 1978.

Hall, Stuart. "Conclusion: The Multi-cultural Question." In Un/settled Multiculturalisms: Diasporas, Entanglements, "Transruptions," edited by Barnor Hesse. London: Zed Books, 2000 .

- - - "New Ethnicities." In Stuart Hall: Critical Dialogues in Cultural Studies, edited by Morley David and K. H. Chen, 441-49. London: Routledge, 1996.

- - - "Notes on Deconstructing 'the Popular.'” In People's History and Socialist Theory, edited by Raphael Samuel, 227-39. History Workshop Series. London: Routledge and Kegan Paul, 1981.

Hardy, Jonathan. Critical Political Economy of the Media: An Introduction. London; New York: Routledge, 2014.

Hesmondhalgh, David. The Cultural Industries. 3rd ed. Thousand Oaks, CA: Sage, 2013.

Hesmondhalgh, David and Anamik Saha. "Race, Ethnicity, and Cultural Production." Popular Communication 11, no. 3 (2013): 179-95.

Hesse, Barnor. Introduction to Un/settled Multiculturalisms: Diasporas, Entanglements, "Transruptions," edited by Barnor Hesse. London: Zed Books, 2000.

Huggan, Graham. The Postcolonial Exotic: Marketing the Margins. London: Psychology Press, 2001.

Keith, Michael. After the Cosmopolitan? Multicultural Cities and the Future of Racism. New York: Routledge, 2005.

Negus, Keith. Music Genres and Corporate Cultures. London: Routledge, 1999.

- - - "The Production of Culture." In Production of Culture/Cultures of Production, 67-118. Thousand Oaks, CA: Sage in association with the Open University, 1997.

Prashad, Vijay. The Karma of Brown Folk. Minneapolis: University of Minnesota Press, 2000.

Ross, Elliot. "The Dangers of a Single Book Cover: The Acacia Tree Meme and 'African Literature."' Africa Is a Country, May 7, 2014.

Ryan, Bill. Making Capital from Culture: The Corporate Form of Capitalist Production. New York: Walter de Gruyter, 1991.

Silverberg, Michael. "The Reason Every Book about Africa Has the Same Cover - and It's Not Pretty." Quartz, May 12, 2014.

Thompson, John B. Books in the Digital Age: The Transformation of Academic and Higher Education Publishing in Britain and the United States. Cambridge: Polity, 2005.

Thornton, Patricia H., and William Ocasio. "Institutional Logics and the Historical Contingency of Power in Organizations: Executive Succession in the Higher Education Publishing Industry, 1958-1990." American Journal of Sociology 105, no. 3 (1999): 801-43. 


\section{(cc) EY-NG-ND}

Copyright (c) 2016 (Anamik Saha). Media Industries is an open-access, peer-reviewed, online academic journal. As such, we aim to participate in the open exchange of information. This work is licensed under a Creative Commons Attribution Noncommercial No Derivatives (by-nc-nd) License. Under this license, this work is available for sharing and noncommercial distribution provided the appropriate attribution is given. 